\title{
Research of asphalt pavement rutting in Vilnius city streets
}

\author{
Audrius Vaitkus ${ }^{\mathrm{a}}$, Donatas Čygas ${ }^{\mathrm{b}}$, Rita Kleizienè $\dot{\mathrm{a}}^{\mathrm{a}}$ \\ ${ }^{a}$ Road Research Institute, Vilnius Gediminas Technical University, Linkmenu str. 28, Vilnius LT-08217, Lithuania \\ ${ }^{b}$ Department of Roads, Vilnius Gediminas Technical University, Sauletekio al. 11, Vilnius LT-10223, Lithuania
}

\begin{abstract}
Permanent deformation in asphalt pavement structures is one of the main pavement distress problems. The common asphalt pavement surface deformations are shoving and rutting at intersections, bus stops and line, in heavy vehicle loaded urban streets, where it is acceleration, deceleration, slow moving or static loading. Considering the occurred asphalt pavement layer rutting can be described as wear, structural and flow rutting. Recently, was observed the increase in severity and extent of rutting (the depth is $40 \mathrm{~mm}$ and more) in asphalt pavement structures in Vilnius city high-streets, bus lines and stops. The purpose of this research was to establish probabilistic (rutted) pavement structures in Vilnius city and to suggest the best treatment solutions. It was found that in many cases the failure was caused by asphalt layers fatigue and low resistance to flow rutting.
\end{abstract}

Keywords: asphalt pavement; rutting; flow rutting; surface corrugation; plastic (permanent) deformation; high modulus asphalt concrete.

\begin{tabular}{|ll}
\hline Nomenclature & \\
AC & Asphalt concrete (hot-mix asphalt) \\
HMAC & High Modulus Asphalt Concrete \\
HVT (F) & Heavy vehicle traffic (flow), $h . v . / d$. \\
IRI & International Roughness Index, $m / k m$ or in. $/$ mile \\
MEPDG & Mechanistic-Empirical Pavement Design Guide \\
RD & Rut depth, $m$ m \\
DMRB & Design Manual for Roads and Bridges \\
REPS & Road of Experimental Pavement Sections \\
MSTR & Multiple Stress Creep and Recovery test \\
APA & Asphalt Pavement Analyser \\
WTT & Wheel Tracking Tester \\
SPT & Simple Performance Test \\
SHRP & Strategic Highway Research Program \\
LTPP & Long Term Pavement Performance \\
\hline
\end{tabular}

\section{Introduction}

Permanent deformation or rutting is most common and significant distresses in flexible pavement influencing pavement structure performance and traffic conditions. Usually rutting and shoving occurs at intersection pavements in asphalt wearing layer. Generally, pavement performance in city streets is different than in national roads, because of the traffic content and flow, driving specific, pavement temperature etc. These differences cause higher severity of pavement distresses, extensive impact to society and road users' expense. Permanent deformations in city streets asphalt pavements causes following concerns [1]:

- Traffic safety. For vehicles, there is reduced frictional characteristics (e.g., wheel path flushing), changing lanes becomes hazardous, there is the risk of loss of control. When water concentrates in the wheel paths potential of ice forming emerge. Longer braking distance of vehicles becomes a potential hazard.

Corresponding author: Audrius Vaitkus. E-mail address: audrius.vaitkus@vgtu.lt

http://dx.doi.org/10.3846/enviro.2014.172

(C) 2014 The Authors. Published by VGTU Press. This is an open-access article distributed under the terms of the Creative Commons Attribution License, which permits unrestricted use, distribution, and reproduction in any medium, provided the original author and source are credited. 
- Driving comfort. Ruts influent steering accuracy and comfort it can lead to car accident.

- Public reaction. The appearance of the roadway results in poor public perceptions and political reactions.

- Expenditure. Rut rehabilitation incurs costs, including user costs due to traffic flow interruptions and increased vehicle maintenance and rehabilitation costs.

The aim of this article is to study pavement distresses types, to highlight commonly occurred distress in Vilnius streets pavement, to analyze rutting and permanent deformation propagation sources, to overlook other countries practice and recommendations for rutting rehabilitation, determine pavement condition in Vilnius city and to suggest reliable solutions for pavement rehabilitation.

\section{Performance of city streets pavements}

There are many factors affecting pavement structure performance such as temperature, water, frost, ageing, load, materials properties and etc. However, the HVT has most damage impact for pavement structure. The HVTF, in main Vilnius city streets pavements, varieties from 2000 to 6000 h.v./d. (Fig. 1), meanwhile in national roads HVTF doesn't reach 1000 h.v./d. [2]. According to population growth and public transport development conception in Vilnius city HVTF, public transport routes and busses number will increase in streets even more [3], [4]. The traffic flows in city streets are irregular during day time, unlike in national roads, this distribution subjected to rush hours (usually from 7 to 10 a.m. and from 4 to 7 p.m. in Vilnius) and weak days (traffic flow during weekend is much reduced).

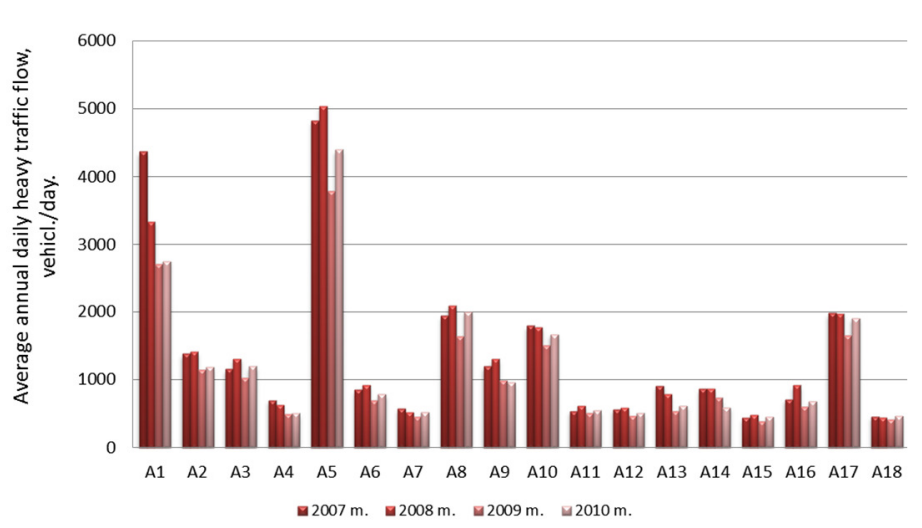

a)

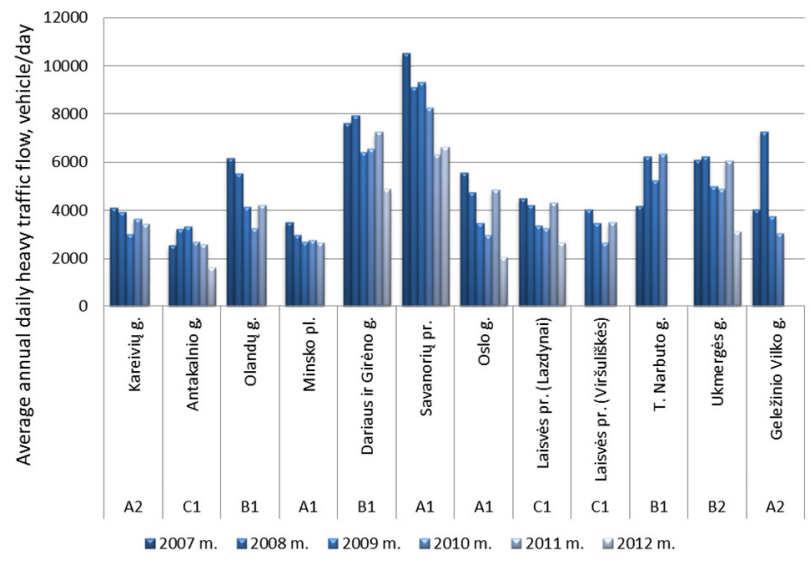

b)

Fig. 1. Average annual daily heavy vehicle traffic flow a) in main national roads of Lithuania b) in main streets of Vilnius city [2]

The distances between vehicles are short. Vehicles are moving continuously and transfer longer loading. Therefore continuous stress and strain influence pavement, without deflection regeneration. Wheels load is describe as static, moving (quasi-static) or dynamic. A static load represent stationary load, which is define as contact geometry and mass of the load. A moving (quasi-static) - moving constant load, which is define as stiffness and mass without damping force in the equation of equilibrium. And a dynamic - changeable moving load which involve inertia, damping, stiffness and mass terms in the equation of motion [5]-[7]. On the other hand, moving vehicle load can be assumed as sum of static load and continuously changing dynamic tire force, which is caused by vehicle response to longitudinal roughness of the surface [8]. Cebon [9] and Gillespie et al. [10] determine that in high speed road damage increases with road roughness. Distresses may reduce the service life of pavement by at least $40 \%$ and even for a smooth pavement and dynamic loads may result in significant increase $(10 \%$ to $15 \%)$ in pavement responses. According to research, rutting damage decreases rapidly with the speed, and mostly influenced (caused) by viscoelastic properties of asphalt mixture [10]. Traffic flow speed in urban territory is lower approx. $50-60 \mathrm{~km} / \mathrm{h}$ and $0-20 \mathrm{~km} / \mathrm{h}$ near the intersections, so loading in streets is more similar to static than dynamic.

Load influence to asphalt pavement varied subjected with climate conditions and surface temperature. Lithuania climate conditions and temperature are similar to other cold regions countries. Asphalt pavement surface temperature varieties from $22^{\circ} \mathrm{C}$ to $+53^{\circ} \mathrm{C}$ [11]. Moreover, freezing/thawing cycles of pavement surface can exceed 80 times and more in year period [12]. Because of extreme climate conditions and avoiding thermal cracking softer bitumen's (50/70) are usually used in asphalt mixtures. From REPS monitoring data the maximum RD growth was observed in pavement structure with asphalt layers from AC 11 VS and AC 16 AS mixtures with bitumen 50/70 [13]. At summer time air temperature is $8-10^{\circ} \mathrm{C}$ higher in urban territory because of air pollution and wind block. Bitumen binder properties decreases at high temperatures $\left(\right.$ to $+60^{\circ} \mathrm{C}$ and more) influencing asphalt mixture strength relaxation [14]. Due to the viscoelastic nature of AC, its behavior highly depends on both temperature and rate of loading. The low-speed of traffic movement at an intersection increases the loading time and thus generates more damage to flexible pavement structures. Moreover, tangential stresses from heavy vehicles braking and accelerating at high temperature increase distresses in asphalt pavement surface [15]. Severe pavement distresses at 
intersections or bus stops, such as AC rutting/shoving or slippage cracking, is clear evidence that static and slow moving load cause's significant pavement deterioration.

In summary, additional loading occurs in city street pavement:

- frequent vehicle acceleration/deceleration (near the crossroads, public transport stops);

- static loading;

- low speed traffic;

- continuous heavy traffic.

\section{Permanent deformation types, causes and indications}

Pavement degradation is a function of pavement roughness and its increase in pavement ageing [16], [17]. From pavement design point of view for asphalt pavement performance usually is analyzed according to fatigue cracking (in the bottom of asphalt base layer) and permanent deformation (in subgrade surface) [18], [19]. Although COST Action 333 [20] summarized responding data shows that flow rutting (or rutting in the bituminous layers) is the most important/common problem in EU countries. Respondents give second place to Loss of skid resistant, third - cracking in the surface, and forth to roughness (longitudinal unevenness) [20]. MEPDG indicate four distresses in asphalt surfaced pavements [21]: alligator cracking, longitudinal cracking, transverse cracking and rutting.

Permanent deformation or rutting is typical asphalt pavement surface distress. Rutting is defined as a longitudinal surface depression in the wheel path [22]. Permanent deformation in one or several pavement layers displays after sufficiently high amount of load repetition. Due to different structure materials properties pavement perform variously at particular loading and climatic conditions. Consequently, different rutting type may occur in asphalt pavement rutting [1], [21], [23], [24]: surface wear, initial densification, structural, and plastic flow rutting.

The surface wear rutting forms only in asphalt top layer, due to progressive loss of coated aggregate particles from the pavement surface, which is caused by combined environmental and tires influence [1], [23], [25]. This problem is not significant when usage of studded tires is controlled [1], [26].

The initial densification rutting forms during the first years of exploitation, due to insufficient compaction of asphalt or all structure layers [23].

The structural rutting is affects in all structure layers and is related with an appropriate pavement design (evaluation of load, weak subgrade, poor drainage, frost action, etc.), materials specification, and construction quality [1], [23], [24]. Usually is reflection of permanent deformation within granular base layers and subgrade.

The flow rutting forms only in asphalt layers and is related with asphalt mixture mechanical properties, air voids content and mixture resistance to share flow.

Flow rutting is the most common rutting type in EU [20]. There are several testing protocols in Europe and in the US for both asphalt binders (MSCR (DSR), Elastometer) and asphalt mixes (SPT, WTT, APA) that examine AC mix resistance to rutting [27], [28]. According to Tarefder et al. [29] significant factor for rutting is temperature, mixtures gradation and moisture. Eddhahak-Ouni et al. [30] research showed that bitumen with PMB presents better rutting factor and less susceptible to temperature. Choi [31] said that shear resistance of a binder at high service temperatures was an important property for the rut resistance of asphalt and determine that dynamic viscosity can be considered as an indicator or rut resistance at low strains. Research showed that rutting resistance of HMAC is twice higher than that of hot mix asphalt, and the fatigue resistance is 510 times higher [32]. Vaitkus and Vorobjovas [33] tested HMAC mixture made from lower quality aggregates but stiffer binders performance. Researchers determined that the lowest rut depth from 10000 WTT cycles was obtained $0.77 \mathrm{~mm}$ in HMAC with crushed granite mineral aggregate and PMB 25/55-60, and RD was 3,5 times smaller than AC 16 AS (with PMB $45 / 80-55)$ which is often use to lay in Lithuania pavement structure.

Table 1. Rutting severity due to rut depth

\begin{tabular}{|c|c|c|c|}
\hline \multirow{2}{*}{ Agency } & \multicolumn{3}{|l|}{ Rut depth } \\
\hline & Low severity level & Medium severity level & High severity level \\
\hline NRC CNRC, Canada [1] & $6.3-12.7 \mathrm{~mm}$ & $12.7-25.4 \mathrm{~mm}$ & $>25.4 \mathrm{~mm}$ \\
\hline Transportation information center [24] & $<12.7 \mathrm{~mm}$ & $<25.4 \mathrm{~mm}$ & $<50.8 \mathrm{~mm}$ \\
\hline $\begin{array}{l}\text { Washington State Department of } \\
\text { Transportation }\end{array}$ & $6.3-12.7 \mathrm{~mm}$ & $12.7-19.1 \mathrm{~mm}$ & $>19.1 \mathrm{~mm}$ \\
\hline Ohio Department of Transportation & $3.2-9.5 \mathrm{~mm}$ & $9.5-19.1 \mathrm{~mm}$ & $>19.1 \mathrm{~mm}$ \\
\hline Texas Department of Transportation [35] & $6.4-12.5 \mathrm{~mm}$ & $12.7-25.2 \mathrm{~mm}$ & $25.4-50.6 \mathrm{~mm}$ \\
\hline DMRB, UK [36] & $<6 \mathrm{~mm}$ & $<11 \mathrm{~mm}$ & $<20 \mathrm{~mm}$ \\
\hline
\end{tabular}

Permanent deformation (rutting) monitoring and mitigation is very important because of its influence on vehicle movement (affecting vehicle tracking), safety (hydroplaning after rain) and dynamic loading (through surface profile variations) [23]. Rutted pavement renovation demand is define through rut depth and severity level. Different agencies present several rutting severity levels (Table 1). The maximum rut depth in subgrade surface of national significance roads in Lithuania is 100- 
$200 \mathrm{~mm}$ depending on maintenance level. The maximum rut depth in pavement surface is $40 \mathrm{~mm}$ [34]. However, rut depth and roughness is not restricted, and there are no confirmed technical documentations for streets maintenance in city streets of Lithuania.

According to SHRP on LTPP study rut transverse profiles can provide information needed to select rehabilitation method such as shape and type of rutting, depth, and lateral location of longitudinal pavement deformations [37]. The actual rutting mechanism also can be observed from transversal profile analysis, which is useful in selecting corrective actions can be made [26]. Gramling et al. [38] analyzed RD measurement techniques and the benefits of surface transverse profiles as opposed to simple rut depth measurements. Researchers grouped RD measurements techniques in to static and dynamic methods. Static procedures that were considered included rod and level, string line, long straightedge, short straightedge, and Face Dipstick ${ }^{\circledR}$ device. Dynamic methods included sensor systems (both ultrasonic and laser) and $35 \mathrm{~mm}$ photography systems. Gramling et al. suggested that transverse profiles, rather than simple rut depths, be measured and that the wire method be used as a standard for reporting rut depths using analysis of the transverse profiles.

For pavement rutting investigation in Vilnius streets transversal profile was measured with long straightedge.

\section{Experimental research}

For the evaluation sixteen distressed pavements of Vilnius city streets were selected. Pavement transverse surface profile was measured in most damage section of the pavement. Measurement were done using $3 \mathrm{~m}$ long ruler (straightedge) which was fixed in horizontal position perpendicular to driving direction. The distance from horizontal line to pavement surface was measured with tape-measure $\pm 1 \mathrm{~mm}$ accuracy every $100 \mathrm{~mm}$.

In order to determine deformation in asphalt layers, 150 diameter cores of pavement were taken in the measuring line. Each core was drilled with 20-30 mm covering. Drilled cores were tested in Road Research Laboratory of Road Research Institute of Vilnius Gediminas Technical University. Every layer thickness and asphalt mixture type was determined. Transversal profile of distressed Vilnius city streets pavements is shown in Table 2. Summarized information, measured RD and severity level of distressed Vilnius city streets pavements is shown in Table 3. 
Table 2. Transversal profile of distressed Vilnius city streets pavements

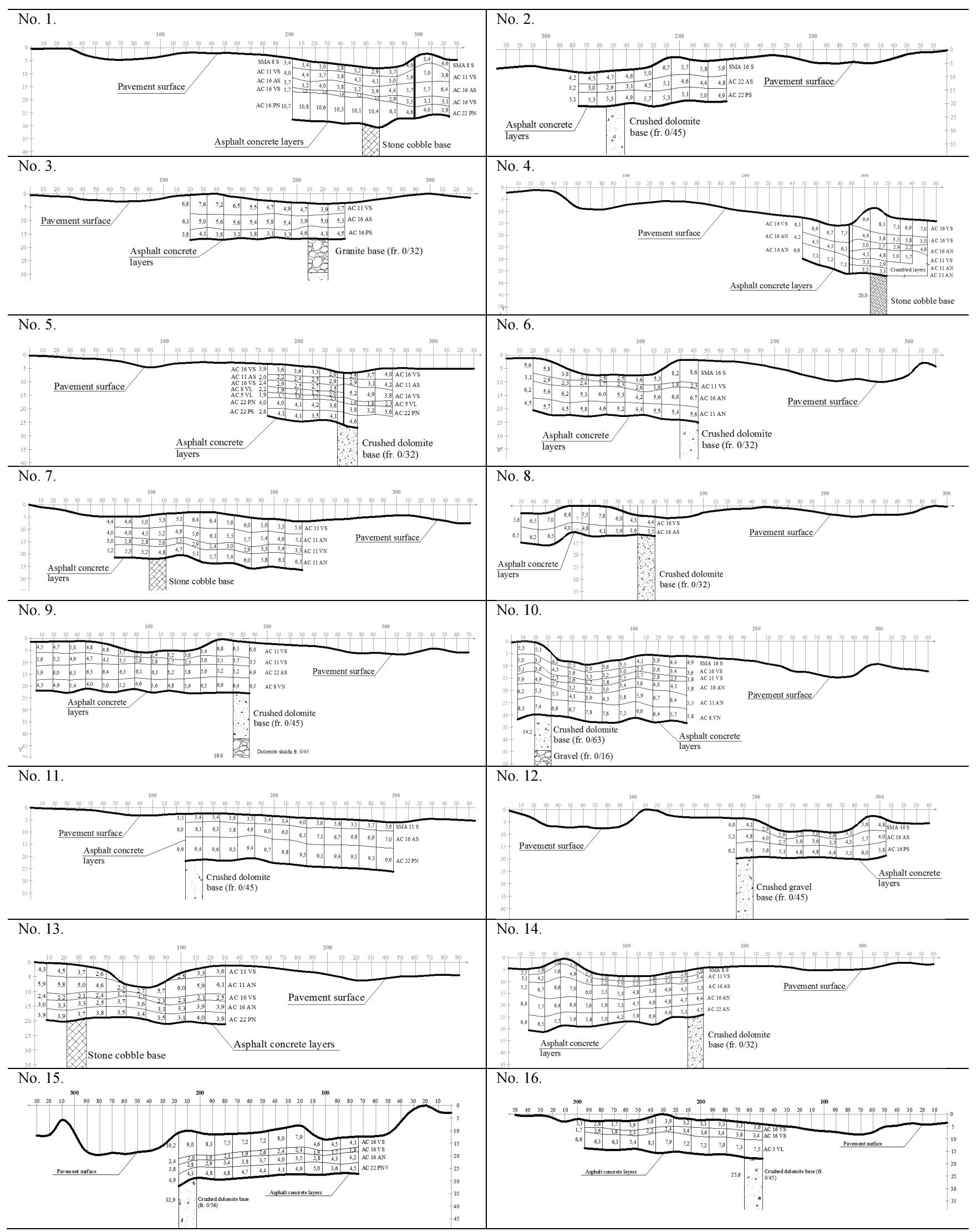

Rut depth varies in very wide range from $10 \mathrm{~mm}$ to $100 \mathrm{~mm}$ and was different depending on wheel side. Define that RD is related with transverse slope of pavement and deeper rut side was the same as slope direction in most cases, accept No 13 and 14 were vehicle flow make turn in opposite direction. 
Table 3. Summarized information, measured RD and severity level of distressed Vilnius city streets pavements

\begin{tabular}{|c|c|c|c|c|c|c|c|c|c|}
\hline \multirow{2}{*}{ 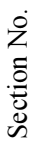 } & \multirow{2}{*}{ Street name } & \multirow{2}{*}{ Site characteristic } & \multirow{2}{*}{$\sum_{I}^{2}$} & \multirow{2}{*}{ 岁畩 } & \multirow{2}{*}{ 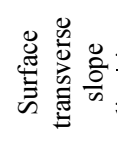 } & \multicolumn{2}{|c|}{$\begin{array}{l}\text { Measured RD, } \\
\mathrm{mm}\end{array}$} & \multirow{2}{*}{ Rutting type } & \multirow{2}{*}{$\begin{array}{c}\text { Severity level } \\
\text { (Acc. NRC CNRC, } \\
\text { see Table 1) }\end{array}$} \\
\hline & & & & & & $\stackrel{\Xi}{\leftrightarrows}$ & $\frac{\vec{z}}{\overrightarrow{000}}$ & & \\
\hline 1. & Savanorių av. & (intersection zone) & 3317 & 235 & right & $35-40$ & $55-60$ & Structural and flow & High \\
\hline 2. & Konstitucijos av. & (bus-stop section) & 580 & 150 & left & $35-40$ & $30-35$ & Structural and flow & High \\
\hline 3. & P.Lukšio str. & (intersection zone) & 264 & 150 & right & $20-25$ & $30-35$ & Initial densification & High \\
\hline 4. & Savanorių av. & (intersection zone) & 522 & 185 & right & $60-65$ & $70-75$ & Structural & High \\
\hline 5. & Ukmergès str. & (uphill section) & 1309 & 195 & right & $15-20$ & $15-20$ & Wear & Medium \\
\hline 6. & Kareiviu str. & (intersection zone) & 482 & 180 & right & $50-55$ & $60-65$ & Flow & High \\
\hline 7. & Nemenčinès rd. & (intersection zone) & 206 & 190 & right & $30-35$ & $30-35$ & Structural and flow & High \\
\hline 8. & Žygimantų str. & (intersection zone) & 771 & 110 & left & $50-55$ & $30-35$ & Structural and flow & High \\
\hline 9. & Saulètekio al. & (bus-stop section) & 786 & 210 & right & $40-45$ & $30-35$ & Flow & High \\
\hline 10. & Kalvarijų str. & (intersection zone) & 657 & 260 & right & $60-65$ & $50-55$ & Structural and flow & High \\
\hline 11. & Geležinio Vilko str. & (intersection zone) & 482 & 195 & right & $10-15$ & $10-15$ & Initial densification & Low \\
\hline 12. & Kalvarijų str. & (intersection zone) & 482 & 160 & right & $65-70$ & $60-65$ & Flow & High \\
\hline 14. & Geležinio Vilko str. & (intersection zone) & 1152 & 250 & left & $60-65$ & $20-25$ & Flow & High \\
\hline 15. & Ozo str. & (bus-stop section) & 318 & 180 & left & $80-100$ & $80-100$ & Flow & High \\
\hline 16. & Kareivių str. & (intersection zone) & 568 & 125 & right & $35-40$ & $55-60$ & Structural and flow & High \\
\hline
\end{tabular}

From the pavement cores can be seen previous pavement rehabilitation solution, usually deformations were fixed by replacing wearing layer or layered 2 or $3 \mathrm{~cm}$ of new AC cores. These solutions were only short term and after 5-7 years works was repeated. From pavement transversal profile no. 1, 10 and 14 can be seen that rutting is caused because of deformations in third and fourth layer. From distressed pavement transversal profiles and measurements were noticed that structural and flow rutting established in most cases (56\%), flow rutting was detected in fourths places (25\%). It can be said, that asphalt mixtures resistance to share flow is too low. All types of permanent deformations were detected in distressed streets pavements: wear rutting (defined in No 5 and 13), initial densification (defined in No 3 and 11); structural rutting (defined in No 7) and flow rutting (defined in No 6, 9, 12, 14 and 15. Also was noticed that high severity flow rutting damage (affected) granular base layer and combine structural and flow rutting was define in No. 1, 2, 4, 8, 10 and 16.

According to research, wear rutting and loss of asphalt aggregate particles can established in aged (old) asphalt wearing layer (when the adhesion between asphalt binder and aggregates is to low) (see profile No 13, from Table 2). Two types of initial densification rut were defined: due to densification in asphalt layers No 3 and due to densification in all structure No 11. Structural rutting (defined in No 7, Table 2) should be rehabilitated by stabilizing granular base layer and laying stiffer AC mixtures. The drainage condition also should be checked and fixed if there will be such a need. From Table 4 can be said, that the deepest rutting defined in No 1, 2, 4, 8, 10, 14 and 16 where all asphalt pavement layers and in some cases aggregate base layer were deformed. Investigation has shown that it is not sufficient to change first AC layer of the pavement, but also have to strengthen pavement. For this purpose deformed layers should be milled and stiffer asphalt mixtures should be laid. On the basis of experimental research have been introduced asphalt pavement structure rutting types (Table 4.)

Table 4. Asphalt pavement structure rutting types

\begin{tabular}{|c|c|c|c|}
\hline Wear rutting & Flow rutting of wearing layer & $\begin{array}{c}\text { Flow rutting of wearing and } \\
\text { binder layer }\end{array}$ & Structural rutting \\
\hline $\begin{array}{l}\text { Rutting is in the wearing layer, } \\
\text { without flow deformations }\end{array}$ & $\begin{array}{l}\text { Rutting is in wearing layer with } \\
\text { flow deformations }\end{array}$ & $\begin{array}{l}\text { Rutting is more than in wearing } \\
\text { layer with flow deformations }\end{array}$ & Deformations in all layers \\
\hline יו1י & & & יו1ו1 \\
\hline $\begin{array}{l}\text { Rehabilitation solutions: } \\
\text { - Surface treatment; } \\
\text { - Hot in-place recycling of } \\
\text { wearing layer; } \\
\text { - Wearing layer replacement. }\end{array}$ & $\begin{array}{l}\text { Rehabilitation solutions: } \\
\text { - Hot in-place recycling of } \\
\text { wearing layer; } \\
\text { - Wearing layer replacement with } \\
\text { stiffer AC. }\end{array}$ & $\begin{array}{l}\text { Rehabilitation solutions: } \\
\text { - Asphalt pavement } \\
\text { strengthening with stiffer AC base } \\
\text { or/and binder layer. }\end{array}$ & $\begin{array}{l}\text { Rehabilitation solutions: } \\
\text { - Pavement structure bearing } \\
\text { capacity improvement. }\end{array}$ \\
\hline
\end{tabular}

Pavement layers thickness for new or rehabilitation structure in Lithuania is selected according to Design Rules of Standardized Pavement Structures KPT SDK 07 [39]. Pavement structure selection for urban territory and for regional roads is the same, by determine pavement structure class. Pavement structures class is determinate according to equivalent standard $10 \mathrm{t}$ axle passes counted for all design period (usual 20 years). According to KPT SDK 07 pavement structure class for pavements were is public transport is III, if buses flow is bigger than 150 buses per day, than high call should be selected. However, this regulation was inappropriate in bus stops in No 2, 9 and 15 streets pavements. According to Germans pavement design rules RStO 12 [40], pavement structure class where is public transport traffic flow is determine considering busses 
traffic (Table 5). In order to avoid rutting in new or rehabilitated pavement structures design rules KPT SDK 07 should renew evaluating precise public transport traffic flow and risk of specific loading in urban territories.

Table 5. Pavement structure class according to public transport traffic flow [40]

\begin{tabular}{lll}
\hline Public transport traffic flow & & Pavement class \\
\hline over 1400 bus/day & - & SV \\
\hline over 425 bus/day & to 1400 bus/day & I \\
\hline over 130 bus/day & to 425 bus/day & II \\
\hline over 65 bus/day & to 130 bus/day & III \\
\hline- & to 65 bus/day & IV
\end{tabular}

There is no documentation for rutting severity level conformation in Lithuania, only maximum RD value $(>40 \mathrm{~mm})$ is determinate in Pavement maintenance guide [34] which is basically intended to use for regional roads maintenance. In order to suspend rutting propagation in asphalt pavement of city streets pavement, management system should be develop for pavement degradation level observation and priority streets for pavement rehabilitation estimation. According to literature review, pavement degradation should be evaluated in further steps: (1) visual site seeing of the pavement; (2) transversal profile measurements; (3) pavement bearing capacity determination using falling weight deflectometer; (4) pavement structure materials sampling and there properties investigation (especially asphalt pavement layers and subgrade soils); (5) all pavement structure exploitation condition evaluation.

Rehabilitation solutions for distressed pavements was carried out according to experimental research, pavement design guides KPT SDK 07 and RStO 12, and Vaitkus and Vorobjovas research [33]. Firstly, pavement structural class was calculated and required structure strength according to traffic flow was selected (Table 5). Than optimal pavement structures using HMAC was carried out. Distressed pavements rehabilitation solutions analysis shown in Table 6 and Fig. 2.

Table 6. Rehabilitation solutions for distressed Vilnius city streets

\begin{tabular}{|c|c|c|c|c|c|c|c|c|c|c|c|c|c|c|c|c|c|}
\hline \multirow[b]{3}{*}{ 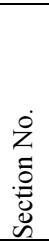 } & \multirow{3}{*}{ 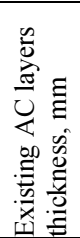 } & \multirow{3}{*}{ 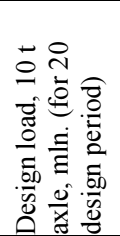 } & \multirow{3}{*}{ 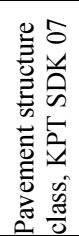 } & \multicolumn{7}{|c|}{ Rehabilitation using standard mixtures } & \multicolumn{7}{|c|}{ Rehabilitation using HMAC mixtures } \\
\hline & & & & \multicolumn{2}{|c|}{$\begin{array}{l}\text { AC base } \\
\text { layer }\end{array}$} & \multicolumn{2}{|c|}{$\begin{array}{c}\text { AC binder } \\
\text { layer }\end{array}$} & \multicolumn{2}{|c|}{$\begin{array}{c}\text { AC wearing } \\
\text { layer }\end{array}$} & \multirow{2}{*}{ 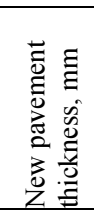 } & \multicolumn{2}{|c|}{$\begin{array}{l}\text { HMAC base } \\
\text { layer }\end{array}$} & \multicolumn{2}{|c|}{$\begin{array}{c}\text { HMAC } \\
\text { binder layer }\end{array}$} & \multicolumn{2}{|c|}{$\begin{array}{c}\text { AC wearing } \\
\text { layer }\end{array}$} & \multirow{2}{*}{ 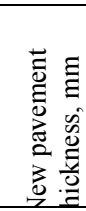 } \\
\hline & & & & 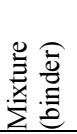 & $\begin{array}{l}\dot{\infty} \\
\stackrel{\Xi}{\Xi} \\
\stackrel{0}{\Xi} \Xi \\
\Xi\end{array}$ & 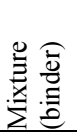 & $\begin{array}{l}\tilde{w} \\
\stackrel{\Xi}{0} \\
\stackrel{\Xi}{\Xi} \Xi \Xi \\
\Xi\end{array}$ & 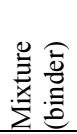 & 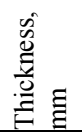 & & 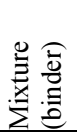 & $\begin{array}{l}\hat{\tilde{D}} \\
\stackrel{\Xi}{\Xi} \\
\stackrel{\Xi}{\Xi} \Xi \\
\Xi\end{array}$ & 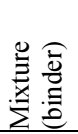 & $\begin{array}{l}\dot{\tilde{D}} \\
\stackrel{\Xi}{\Xi} \\
\stackrel{\Xi}{\Xi} \Xi \\
\Xi\end{array}$ & 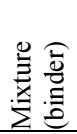 & $\begin{array}{l}\dot{0} \\
\stackrel{\Xi}{E} \\
\stackrel{\Xi}{\Xi} \Xi \\
\Xi\end{array}$ & \\
\hline 1 & 235 & 36.74 & SV & & 180 & & 80 & & 40 & 300 & & 130 & & 70 & & 30 & 230 \\
\hline 2 & 150 & $\begin{array}{l}{ }^{1580 \mathrm{~b} /} \\
\mathrm{d}\end{array}$ & ${ }^{1} \mathrm{I}$ & & 140 & & 80 & & 40 & 260 & & - & & 60 & & 30 & 90 \\
\hline 3 & 150 & 0.84 & III & & - & & ${ }^{3} 40$ & & 40 & 80 & & - & & 50 & & 30 & 80 \\
\hline 4 & 185 & 3.32 & II & & 100 & & 80 & & 40 & 220 & & 80 & & 50 & & 30 & 160 \\
\hline 5 & ${ }^{2} 195$ & - & - & & - & & - & & - & - & & - & & - & & - & - \\
\hline 6 & 180 & 3.41 & II & & 100 & & 80 & & 40 & 220 & & - & & 70 & & 30 & 100 \\
\hline 7 & 190 & 1.93 & III & & 100 & & 40 & & 40 & 180 & & - & & 70 & & 30 & 100 \\
\hline 8 & 110 & 4.91 & II & & 100 & in & 80 & $\frac{6}{n}$ & 40 & 220 & के & - & ڤ્ & 80 & $\frac{6}{n}$ & 30 & 110 \\
\hline 9 & 210 & & I & $\stackrel{?}{\stackrel{2}{0}}$ & - & $\stackrel{\infty}{\infty}$ & 120 & $\frac{\infty}{\infty}$ & 40 & 160 & $\frac{n}{n}$ & - & $\frac{n}{n}$ & 60 & $\stackrel{\infty}{\infty}$ & 30 & 90 \\
\hline $\begin{array}{l}1 \\
0\end{array}$ & 260 & 4.18 & II & $\frac{\sim}{2}$ & 100 & 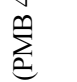 & 80 & $\sum_{i=1}^{\infty}$ & 40 & 220 & $\sum_{i}^{\infty}$ & - & $\sum_{\varrho}^{n}$ & 80 & $\sum_{\varrho}^{\oplus}$ & 30 & 100 \\
\hline $\begin{array}{l}1 \\
1\end{array}$ & ${ }^{2} 195$ & - & - & ปู & - & $\begin{array}{l}\text { 艺 } \\
\text { ป }\end{array}$ & - & 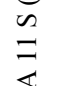 & - & - & Ũ & - & $\frac{0}{2}$ & - & $\begin{array}{l}\approx \\
\approx\end{array}$ & - & - \\
\hline $\begin{array}{l}1 \\
2\end{array}$ & 160 & 3.2 & II & & 40 & $\underset{\psi}{U}$ & 80 & $\sum_{n}^{\longleftarrow}$ & 40 & 160 & $\sum_{I}$ & - & $\sum_{I}$ & 80 & $\sum_{n}$ & 30 & 110 \\
\hline $\begin{array}{l}1 \\
3\end{array}$ & 180 & 5.8 & II & & 100 & & 80 & & 40 & 220 & & - & & 80 & & 30 & 110 \\
\hline $\begin{array}{l}1 \\
4\end{array}$ & 250 & 6.38 & II & & 100 & & 80 & & 40 & 220 & & - & & 80 & & 30 & 110 \\
\hline $\begin{array}{l}1 \\
5\end{array}$ & 180 & 2.94 & III & & 100 & & 40 & & 40 & 180 & & - & & 50 & & 30 & 80 \\
\hline $\begin{array}{l}1 \\
6\end{array}$ & 125 & 5.25 & II & & 100 & & 80 & & 40 & 220 & & - & & 80 & & 30 & 110 \\
\hline
\end{tabular}

${ }^{1}$ Pavement structure class was determine according to bus number per day, look to Table 5 .

${ }^{2}$ Pavement is in good condition, suggested to do low deep hot in-place recycling or to change waering layer when RD increese more

${ }^{3}$ For this layer was selected AC 16 AS mixture with PMB 45/80-55 binder. 


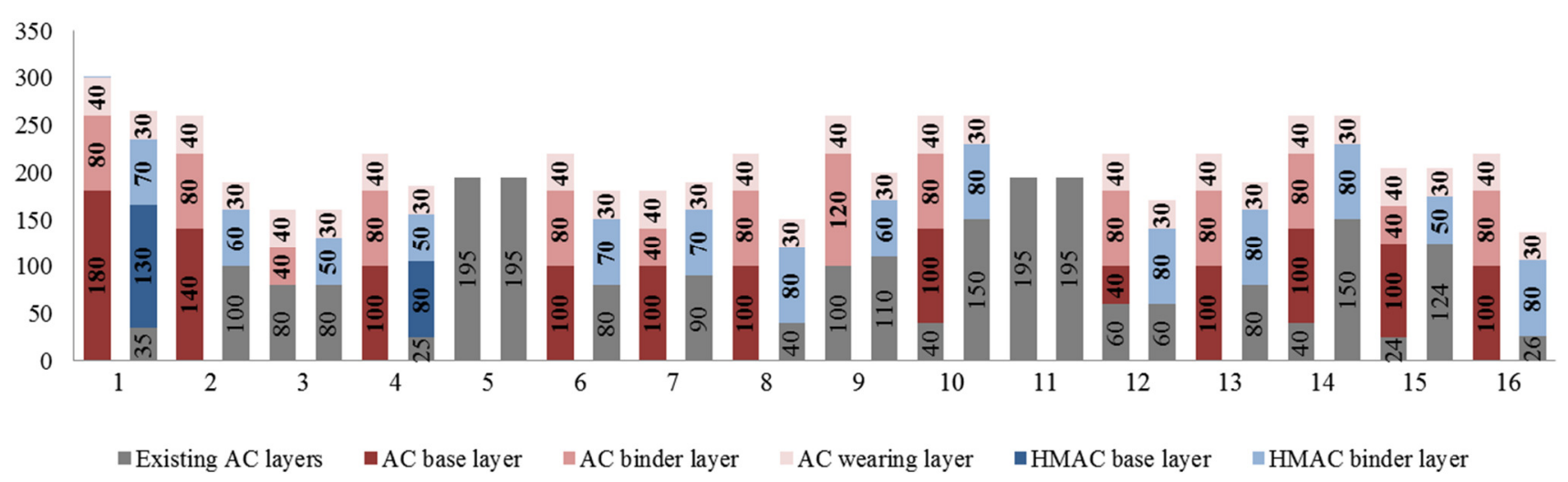

Fig. 2. Comparison of asphalt layers thickness dependent on rehabilitation solutions (pavement thickness shown in mm)

\section{Conclusions}

Rehabilitation solution can be identified from transversal profile of distressed pavement surface.

The most common distress of Vilnius city streets is rutting influenced by asphalt wearing or asphalt wearing and binder layers shear flow.

Distresses of city streets can be grouped to wear rutting, flow rutting of wearing layer, flow rutting of wearing and binder layer, and structural rutting.

Two pavement rehabilitation methods are most promising (hot in-place recycling of only wearing layer and use of high modulus asphalt concrete). The rehabilitation method selection suggested dependent on pavement severity level. It should be used only appropriate rehabilitation method for distressed pavement rehabilitation to ensure long term result.

\section{References}

[1] NRC CNRC. 2003. Rut Mitigation Techniques at Intersections. Road and Sidewalks, Federation of Canadian Municipalities and National Research Council, Canada. $48 \mathrm{p}$.

[2] Vaitkus, A.; Vorobjovas, V.; Kleizienè, R.; Šernas, O.; Žiliūtè, L. 2013. Resistant to plastic deformation (rutting) asphalt pavement modeling, design and research in Vilnius city streets [Vilniaus miesto gatvių asfalto dangų, atsparių plastinių deformacijų (prověžų) susidarymui, modeliavimas, projektavimas ir tyrimai], Infrastructure department of Municipality of Vilnius city, Lithuania. $148 \mathrm{p}$.

[3] Ušpalytè-Vitkūnienè, R.; Burinskienè, M.; Grigonis, V. 2012. Trends of Public Transport Development in Vilnius : Passengers Flows Simulation and Economical Feasibility, in Proc. of the 2012 International Conference on Electronics, Information and Communication Engineering (EICE 2012), 98104.

[4] Jakimavičius, M.; Burinskienè, M. 2013. Multiple criteria assessment of a new tram line development scenario in Vilnius City public transport system, Transport 28(4): 431-437. http://dx.doi.org/10.3846/16484142.2013.869253

[5] Woodrooffe, J. H. F. and LeBlanc, P. A. 1986. Heavy Vehicle Axle Dynamics, in Proc. of the International Symposium on Heavy Vehicles Weights and Dimensions, Kelowna, British Columbia, Canada, 25-35.

[6] Oecd Scientific Expert Group. 1992. Dynamic Loading of Pavements: Road Transport Research. Organization for Economic, 184 p. ISBN-13: $978-$ 9264137622

[7] Yoo, P. and Al-Qadi, I. L. 2007. Effect of Transient Dynamic Loading on Flexible Pavements, Transp. Res. Rec. 1990(1): 129-140.

[8] Back, J.; Ozer, H.; Wang, H.; Al-Quadi, I. L. 2010. Effects of Interface Conditions on Reflective Cracking Development in Hot-Mix Asphalt Overlays, Road Mater. Pavement Des. 11(2): 307-334. http://dx.doi.org/10.3166/rmpd.11.307-334

[9] Cebonl, D. 1986. Road Damaging Effects of Dynamic Axle Loads, in Proc. of the International Symposium on Heavy Vehicles Weights and Dimensions, Kelowna, British Columbia, Canada, 37-53.

[10] Gillespie, T. D.; Karamihas, S. M.; Cebon, D.; Sayers, M. W.; Nasim, M. A.; Hansen, W.; Ehsan, N. 1992. Effects of heavy vehicle characteristics on pavement response and performance, in National Cooperative Highway Research Program Transportation Research Board National Research Council, USA. $255 \mathrm{p}$

[11] Vaitkus, A.; Laurinavičius, A.; Oginskas, R.; Motiejūnas, A.; Paliukaitè, M.; Barvidienė, O. 2012. The Road of Experimental Pavement Structures: Experience of Five Years Operation, Balt. J. Road Bridg. Eng. 7(3): 220-227.

[12] Jukneviciute-Zilinskiene, L. 2009. Methodology for the Evaluation of the Efect of Climate of Lithuania on Road Construction and Climatic Regioning. Technika, Vilnius. 125 p. ISBN 978-9955-28-510-6.

[13] Vaitkus, A. and Paliukaite, M. 2013. Evaluation of Time Loading Influence on Asphalt Pavement Rutting, Procedia Eng. 57: 1205-1212. http://dx.doi.org/10.1016/j.proeng.2013.04.152

[14] Paliukaite, M. and Vaitkus, A. 2011. Analysis of Tempreture and Moisture Influenc on Asphalt Pavement Strenght, in Proc. of the 8th International Conference on Environmental Engineering. Vilnius, Lithuania, 1160-1165.

[15] Wang, H. and Al-Qadi, I. L. 2010. Evaluation of Surface-Related Pavement Damage due to Tire Braking, Road Mater. Pavement Des. 11(1): 101-121. http://dx.doi.org/10.1080/14680629.2010.9690262

[16] Fwa, T. F.; Pasindu H. R.; Ong, G. P. 2012. Critical Rut Depth for Pavement Maintenance Based on Vehicle Skidding and Hydroplaning Consideration, J. Transp. Eng. 138(4): 423-429. http://dx.doi.org/10.1061/(ASCE)TE.1943-5436.0000336

[17] Mogawer, W. S.; Austerman, A. J.; Daniel, J. S.; Zhou, F.; Bennert, T. 2011. Evaluation of the effects of hot mix asphalt density on mixture fatigue performance, rutting performance and MEPDG distress predictions, Int. J. Pavement Eng. 12(2): 161-175. http://dx.doi.org/10.1080/10298436.2010.546857 
[18] FGSV 498. 2009. Richtlinien für die rechnerische Dimensionierung des Oberbaus von Verkehrsflächen mit Asphaltdeckschicht RDO Asphalt 09 [Guidelines for mathematical dimensioning of foundations of traffic surfaces with a course asphalt surface]. Forschungsgesellschaft für Straßen- und Verkehrswesen, Köln, Germany. 36 p.

[19] Huang, Y. H. 2004. Pavement Analysis and Design, 2nd ed. New Jersey: Pearson Prentice Hall. 785 p. ISBN 0-13-142473-4.

[20] COST 333. 1999. Development of New Bituminous Pavement Design Method. European Commission Directorate General Transport (ECSC-EECEAEC), Brussel, Luxembourg, 375 p. ISBN: 92-828-6796-X.

[21] NCHRP 1-37A. 2004. Guide for Mechanistic-Empirical Design of New and Rehabilitated Pavement Structures, National Cooperative Highway Research Program Transportation Research Board National Research Council, Champaign, Illinois, USA. 411 p.

[22] Miller, J. S.; Bellinger, W. Y. 2003. Distress Identification Manual for the Long-Term Pavement Performance Program, Fourth Revised Edition (FHWARD-03-031), Federal Highway Administration, McLean, VA, USA. 164 p.

[23] Morosiuk, G.; Riley, M. 2004. Highway development \& Management. Volume 6. Modelling Road Deterioration and Works Effects in HDM-4. World Road Association. 296 p. ISBN: 2-84060-102-8.

[24] Walker, D.; Entine, L.; Kummer, S. 2002. Pavement Surface Evaluation and Rutting. Asphalt Roads, Transportation Information Center University of Wisconsin-Madison, USA. 26 p.

[25] Oscarsson, E. 2011. Evaluation of the Mechanistic-Empirical Pavement Design Guide model for permanent deformations in asphalt concrete, Int. J. Pavement Eng. 12(1): 1-12. Feb. 2011. http://dx.doi.org/10.1080/10298430903578952

[26] NCHRP Report.468. 2002. Contributions of Pavement Structural Layers to Rutting of Hot Mix Asphalt Pavements, National Cooperative Highway Research Program, Washington, USA. 165 p.

[27] Bernier, A.; Zofka, A.; Yut, I. 2012. Laboratory evaluation of rutting susceptibility of polymer-modified asphalt mixtures containing recycled pavements, Constr. Build. Mater. 31: 58-66. http://dx.doi.org/10.1016/j.conbuildmat.2011.12.094

[28] Perraton, D.; Benedetto, H.; Sauzéat, C.; Roche, C.; Bankowski, W.; Partl, M.; Grenfell, J. 2010. Rutting of bituminous mixtures: wheel tracking tests campaign analysis, Mater. Struct. 44(5): 969-986. http://dx.doi.org/10.1617/s11527-010-9680-y

[29] Tarefder, R. A.; Zaman, M.; Hobson, K. 2003. A Laboratory and Statistical Evaluation of Factors Affecting Rutting, Int. J. Pavement Eng. 4(1): 59-68. http://dx.doi.org/10.1080/10298430310001593263

[30] Eddhahak-Ouni, A.; Dony, A.; Colin, J. 2012. Prediction of the rutting potential of bituminous binders using a stochastic approach, Road Mater Pavement Des. 13(1): 38-48. http://dx.doi.org/10.1080/14680629.2011.644061

[31] Choi, Y. K. 2011. Visco-Elastic Analysis of the Elastomeric Binder Shear Resistance in Relation to Asphalt Rutting, Road Mater. Pavement Des. 12(4): 767-794. http://dx.doi.org/10.1080/14680629.2011.9713894

[32] Lee, H. J.; Lee, J. H.; Park, H. M. 2007. Performance evaluation of high modulus asphalt mixtures for long life asphalt pavements, Constr. Build. Mater. 21(5): 1079-1087. http://dx.doi.org/10.1016/j.conbuildmat.2006.01.003

[33] Vaitkus, A.; Vorobjovas, V. 2013. Use of local aggregates in high modulus asphalt concrete layers, Građevinar 65(4): 353-360.

[34] LAKD. 2005. Guide to Road Maintenance [Kelių priežiūros vadovas] Part I. KPV PN-05. Lithuaniai Road Administration under the Ministry of Transport and Communications, Vilnius, Lithuania. $50 \mathrm{p}$.

[35] Texas Department of Transportation. 2011. Pavement Design Guide. Texas Department of Transportation, USA, $427 \mathrm{p}$

[36] DMRB. 2008. Data for Pavement Assessment HD 29/08. The Highways Agency; Scottish Government; Welsh Assembly Government; The Department for Regional Development Northern Ireland, London, UK. 94 p.

[37] Fang, H.; Haddock, J. E.; White, T. D.; Hand, A. J. 2004. On the characterization of flexible pavement rutting using creep model-based finite element analysis, Finite Elem. Anal. Des. 41(1): 49-73. http://dx.doi.org/10.1016/j.finel.2004.03.002

[38] Gramling, W. L.; Hunt, J. E.; Suzuki, G. S. 1991. Rational Approach to Cross-Profile and Rut Depth Analysis. Transportation Research Record No. 1311. Transportation Research Board, National Research Council, Washington D.C., USA, 173-179.

[39] LAKD. 2008. Design rules of Road Standardized Pavement Structures [Automobilių Kelių Standartizuotų Dangų Konstrukcijų Projektavimo Taisyklès KPT SDK 07]. Lithuaniai Road Administration under the Ministry of Transport and Communications, Vilnius, Lithuania. $42 \mathrm{p}$.

[40] FGSV 499. 2012. Desing rules for standartized pavement structures [Richtlinien für die Standardisierung des Oberbaus von Verkehrsfächen] RStO 12 Forschungsgesellschaft für Straßen- und Verkehrswesen, Köln, Germany. 52 p. ISBN: 978-3-86446-021-0. 